\title{
The Opinions of Turkish Learning Foreign Students about the Educational System in Turkey and Their Respective Countries, Turkish Language and the Language Areas
}

\author{
Betul Keray Dincel ${ }^{1}$ \\ ${ }^{1}$ Faculty of Education, Aksaray University, Aksaray, Turkey \\ Correspondence: Betul Keray Dincel, Faculty of Education, Aksaray University, Aksaray, Turkey.
}

Received: November 15, 2018

Accepted: December 30, $2018 \quad$ Online Published: March 20, 2019

doi:10.5539/ies.v12n4p156

URL: https://doi.org/10.5539/ies.v12n4p156

\begin{abstract}
Today, it is not enough for individuals to only speak a native language. Individuals feel the need to learn a second or more language. In the developing world, it is seen that by the help of the technology people can reach the world from home and can learn one or more languages and may even grow in a multicultural family and become bilingual. In this research, it is aimed to investigate the views of Turkish learning international students on the education system in their countries, the education system in Turkey, Turkish and the language areas they study. The purposive sampling method was used in this study. In order to collect qualified data, B2 level students who can easily express themselves in Turkish were selected and interviewed. The research survey was applied to 30 students who were volunteers. To obtain in-depth information, the semi-structured interview method was decided to be used. In this study, it is seen that Turkmen students are not satisfied with the education system in their country while Azerbaijanis are satisfied and both groups liked the education system in Turkey. It is determined that the learners have positive and beautiful thoughts about Turkish. In terms of linguistic areas they do not find listening necessary, they do not mind much about reading, and on the contrary, they care a lot about speaking, and they give importance to writing and grammar, though they have difficulties in both.
\end{abstract}

Keywords: Turkish learning foreign students, Turkish, language skill, education

\section{Introduction}

There are thousands of languages in the world that are actively spoken. A language must be spoken in order to live. Languages which are not spoken are obliged to die. According to Ungan (2013), language is the use of the mechanism that allows the production of an unlimited number of sentences with a limited number of sounds by human beings. The language development of human beings is formed by bringing together these few elements and creating a concept network that has semantic integrity. While sounds form words, words form sentences, meaningful and subtle use of language improves the language itself, the transfer of the developing language to younger generations also contributes to the growing individuals with the richness of that language.

Today, it is not enough for individuals to only speak a native language. Individuals feel the need to learn a second or more language. In the developing world, it is seen that by the help of the technology people can reach the world from home and can learn one or more languages and may even grow in a multicultural family and become bilingual.

As Mete describes (2015), the objectives that a foreign language student should have are as follows:

1) To understand someone who speaks a foreign language,

2) To speak a foreign language in a comprehensible way,

3) To read and understand an article written in a foreign language,

4) To write in a comprehensible way,

5) To have a more or less idea about the culture and traditions of the nation who speak the language learned and to understand their way of life.

In the language teaching, five language areas are taught: listening, reading, speaking, writing and grammar. According to Rost (2001), listening is used in language teaching to refer to a complex process that allows us to 
understand spoken language. Listening often occurs in conjunction with other skills such as speaking, reading, and writing. Listening is not only a skill area in language performance but is also a critical means of acquiring a second language. Listening is the channel in which we process language in real time - acquiring pacing, units of encoding and pausing that are unique to the spoken language.

The student's understanding of what he/she is listening helps all language skills, especially speaking. Reading helps students a new language learning process via many themes such as vocabulary, grammar, culture, etc.

Reading strategies are the mental operations involved when readers approach a text effectively and make sense of what they read. These problem-solving techniques include guessing word meanings from context and evaluating those guesses, recognizing cognates and word families, skimming, scanning, reading for meaning, predicting, activating general knowledge, making inferences, following references, and separating main ideas from supporting details (Barnett, 1988, p. 150).

According to Keskin and Okur (2013), it is possible that reading in a foreign language is less permanent in terms of the duration of the memory. While the learner performs the reading activity in a more extended period, the words and the sentences are more difficult and analyzing, and understanding is a long process. A basic or intermediate level reader is much more interested in the linguistic details of the text, so it is very likely that there is some time lost within which the textual information is deleted from the memory. Therefore, the language learner may have problems in establishing a relationship between the information given in the text and understanding the whole concept. As the person expands his/her vocabulary, he/she becomes better in understanding the context of the text in a shorter time without losing the focus.

Williams (1986) described the top ten principles for teaching reading as follows:

1) In the absence of interesting texts, very little is possible.

2) The primary activity of a reading lesson should be learners reading texts.

3) Growth in language ability is an essential part of the development of reading ability.

4) Classroom procedure should reflect the purposeful, task-based, interactive nature of real reading.

5) Teachers must learn to be quiet: all too often, teachers interfere with and so impede their learners' reading development by being too dominant and by talking too much.

6) Exercise-types should, as far as possible, approximate to cognitive reality.

7) A learner will not become a proficient reader by merely attending a reading course or working through a reading textbook.

8) A reader contributes meaning to a text.

9) Progress in reading requires learners to use their ears, as well as their eyes.

10) Using a text does not necessarily equal to teaching reading.

Another skill of language learning which is speaking is seen indispensable in everyday life. Particularly when we consider the international students who learn Turkish in a natural environment of Turkey, speaking is much more critical for them. The more they speak and learn and the more comfortable they notice the mistakes they make during their conversations. In fact, in some cases, it is possible to learn a lot of words or expressions from people whose native language is Turkish.

The skills are also affected by the context. Speaking is typically reciprocal: any interlocutors usually are all able to contribute simultaneously to the discourse and to respond immediately to each other's contributions. Further, speaking is physically situated face-to-face interaction: usually, speakers can see each other and so can refer to the physical context and use some physical signals to indicate, for instance, attention to the interaction, their intention to contribute and their attitude towards what is being said. Hence, speech can tolerate more implicit reference (Bygate, 2001, p. 16). The important thing in the conversation is not just expressing feelings and thoughts in words. The emphasis, intonation, diction, and pronunciation must also be correct during the statement (Ucgun, 2007, p. 64).

According to Bygate (2001, p. 17), the following points should be considered in speech teaching:

- A range of different types of interaction needs practicing.

- The conditions of oral tasks need to differ from those for written skills.

- Improvised speech needs practice, but around some content familiarity. 
- Overt oral editing skills need to be encouraged, including the use of communication strategies.

- Oral language processing requires integration of accuracy, complexity, and fluency.

- For learners' oral abilities to develop, courses need to vary the emphasis on fluency, accuracy, and complexity.

Effective use of writing skills in a foreign language is not easy. Good use of writing skills requires a good learning of the target language as well as a severe cognitive process. For this reason, the majority of foreign language learners state that writing is the most challenging area. The stages of writing in teaching Turkish as a foreign language are teaching the alphabet, words, sentences, paragraphs, and texts (Bagci \& Basar, 2013, p. 310).

Grammar; while originating from the natural structure of the language also is the system which makes it possible for different language functions meet within the body of common rules especially communication. Having command of the language used, speaking and writing it correctly require strong grammar knowledge. However only knowing the rules cannot be the indicator of using the language correctly and effectively. For the individual, who learns the rules of the language but cannot transform it into daily life, grammar teaching can be difficult and tedious (Demir \& Erdogan, 2017).

It is useful to teach the grammar reinforcing it with the other skills without causing the learner to get bored. There are several studies on the problems of international students learning Turkish (Acik, 2008; Bagci \& Basar, 2013; Candas-Karababa, 2009; Bicer, Coban, \& Cakır, 2014).

In this research rather than the problems it is aimed to investigate the views of Turkish learning international students on the education system in their countries, the education system in Turkey, Turkish and the language areas they study.

\section{Method}

This research is a qualitative study aiming to determine the opinions of international students in Turkish language and their language skills. Since it is not possible to observe all the course periods of the students, the most common interview method in qualitative studies has been preferred to use to evaluate their experiences and opinions. According to Punch (2005), interviewing is one of the primary data collection tools. Interviewing is a way of understanding people's perceptions, meanings, definitions and construction of reality. It is also one of the most powerful methods used to understand others.

The purposive sampling method was used in line with the aim of the study. To collect qualified data, B2 level students who can easily express themselves in Turkish were picked and interviewed. The research survey was applied to 30 students who were volunteers. The participants consist of 15 Turkmen and 15 Azerbaijani students who came to Turkey for a bachelor's degree and learn Turkish in Aksaray University Turkish Language Teaching Center. Participants were the students who studied Turkish at least six months (one academic year) in Turkey.

To obtain in-depth information, the semi-structured interview method was decided to be used. In the research, a pool was created from open-ended questions. A preliminary interview was done to get the opinions of three experts who taught Turkish to foreigners and three participants and after this four open-ended questions were decided to be asked in the real interviews.

The questions are as follows:

1) What do you think about the education system in your country?

2) What do you think about the education system in Turkey?

3) How do you think Turkish is as a language?

4) As you know, you are learning Turkish focusing on reading, listening, speaking, writing and grammar. What do you think about these language areas?

In the interview process, to keep the students motivated, firstly some easy questions were directed to the students such as what they thought about the education system in Turkey and their countries. Then their views on Turkish and the language areas they studied were asked. During the interview, an audio recording was used with the permission of the participants.

Afterward, interview records were transcribed, and a data of 33 pages were created. In the analysis of the data, each participant was given a code from 1 to 30 . The views of international students learning Turkish were analyzed systematically by reading the data one by one. While reading the students responses were written in code form beside each sentence. Through coding, it is possible to combine and associate opinions that are similar in meaning. After preparing all opinions and codes related to the questions, the codes were tried to be grouped again. The 
resulting codes and themes were arranged, frequency distributions were added, at this stage, the information was processed without any comments and presented in the findings section. The data were analyzed using the NVivo 11 Pro program. Two experts made separate encodings, and then the similarities and differences between the codes were compared. According to the recurrence percentile formula (Reliability $=$ Number of agreements/Number of agreements + disagreements) (Miles \& Huberman, 1994), the reliability of the interview analysis was 0.93 .

\section{Results}

The results part includes the findings from the opinions of students who choose Turkish as a foreign language about the education system in their own country, the education system in Turkey, Turkish language and language skills. Participants first evaluated the education system in their own country, and the findings are as shown in Table 1.

Table 1. Opinions of the participants about the education system in their countries

\begin{tabular}{lll}
\hline Country & Code & $\mathrm{f}$ \\
\hline \multirow{5}{*}{ Not good } & 3 \\
& Teachers give good notes for money & 1 \\
& It is difficult to study in the university & 3 \\
& Universities are mercenary & 3 \\
& Sage and intelligent people could not get an education & 1 \\
& The ones who do not have money can not pass the exams & 1 \\
& People can get a diploma with paying but without attending classes & 1 \\
& The education level is slightly low & 2 \\
& The teachers are unconcerned & 2 \\
\hline & The education system is good & 7 \\
& The ones who study at private universities cannot find jobs & 2 \\
& The teachers give higher notes for money & 2 \\
& The private colleges are expensive & 2 \\
& The university entrance exam is hard & 1 \\
& Similar to Turkey
\end{tabular}

When evaluating the education system in Turkmenistan, the students stated that the education system was not good, the university was challenging to study, they could not go to university because they were mercenary, the education system was at quite a low level, and the teachers were not concerned with the students.

The opinions of some Turkmen students are as follows:

"There are only state universities. Besides they are too expensive. It is even more expensive than private universities here. It is tough to enter universities with our resources. So we cannot be admitted only with our success and without paying money." (3)

"The education system in Turkmenistan is based on material staff. You can study in better conditions if you have money. Then your horizon is clear. So I think the situation is too bad. Very wise, intelligent people are not allowed to proceed. So even if you get a good sore in the university entrance exam and your score is decreased down. So without paying, only with your success, you cannot get into college." (6)

"Even if you do not go to school or do nothing, they give you good marks. I have to come to school to get a diploma here, and there if you pay for it, you can get a diploma without going to school." (7)

"Public universities in Turkmenistan are more expensive than private universities here. Everyone can study in their own country, but I do not have a chance to study in Turkmenistan because universities are costly." (12)

Azerbaijani students generally stated that the education system in their country is good. The opinion of an Azerbaijani student is as follows:

"The education system in my country is good. If I studied in my country, I could finish university in 4 years, but I came here because the university entrance exam was difficult there. I thought I could not make it. I would love to study in my country. Our education system is excellent."

At the end of the process of learning Turkish for six months (one semester of tuition) the views of the participants on the education system in Turkey are as in Table 2. 
Table 2. Participants' opinions about the education system in Turkey

\begin{tabular}{ll}
\hline Code & f \\
\hline Same as his/her country & 6 \\
Very good & 4 \\
Possibility to enter university with own knowledge & 1 \\
Being better than his/her country & 3 \\
The teachers are concerned with the students & 2 \\
The college fees are reasonable in Turkey & 1 \\
Turkey has a developed education system & 1 \\
Students cannot get a diploma without passing the exams & 1 \\
\hline
\end{tabular}

The students often liken the education system in Turkey with their country. They also stated that the education system is very good in Turkey even better than in their country and the teachers are concerned with the students. The statements of some students are as follows:

"In my opinion good. Everything is good. Here is not as hard as Turkmenistan." (7)

"I find it nice. We have everything here. It is cheap here to study in college." (12)

"Everything regarding education is better here. In our country, it is not that developed." (14)

"The education system is better than our country because in Turkey it does not matter if you study 5 or 6 years you need to either pass the exams or continue studying. This shows that in Turkey they focus more on the education system. They do not leave the students alone. If you can not pass even one exam, you can not get your diploma." (18)

The opinions of the participants about the Turkish language they have studied for six months are as follows:

Table 3. Participants' views on the Turkish language

\begin{tabular}{ll}
\hline Code & $\mathrm{f}$ \\
\hline The similarity to the mother tongue & 9 \\
Ability to comprehend Turkish & 1 \\
The necessity to improve a little & 1 \\
Turkish is a beautiful language & 5 \\
Turkish is a polite language & 2 \\
Turkish is easy to communicate & 7 \\
Turkish is a rich language & 1 \\
Turkish is an enjoyable language & 1 \\
Turkish is different from the mother tongue & 2 \\
The Turkish language is like music & 1 \\
Turkish is a warm language & 1 \\
Turkish is an easy language & 10 \\
Turkish pronunciation is good & 1 \\
Turkish is easy to learn & 1 \\
\hline
\end{tabular}

Generally, students find Turkish similar to their mother tongue, a natural language to learn, easy to communicate and a beautiful language. Also, they described the Turkish language as lovely, polite, enjoyable, like melody, warm and comfortable to learn. The statements of some students are as follows:

"Turkish is nice and pleasant. Nice words exist in it. I speak very pleasantly with friends. They use words such as my love, sweetheart, dear, etc." (2)

"I think Turkish is a very polite language. Speaking and communicating is easy. If compared with Russian or Turkoman, Turkish is much more polite in terms of communicating with someone." (2)

"It is an enjoyable language. There are many words in it. Turkish is like a melody to me." (5)

"It is a straightforward language for us. The words are nice. It is nice to speak with people. In our language expressions such as how are you? Are you good? Thank you or good luck with what you are doing do not exist." (11) 
"Turkish is very similar to the Azerbaijani language as in dialect. It is not confusing for me. I mean I can learn it quickly.” (15)

"I think Turkish is an easy language and everybody can speak Turkish in Azerbaijan. Our traffic rules are in Turkish. Most of the TV series we watch are in Turkish. I can easily communicate with teachers and understand the words." (18)

The views of the participants on the language areas in which they learn Turkish, listening, reading, speaking, writing and grammar are shown in Table 4.

Table 4. Participants' views on language areas

\begin{tabular}{|c|c|c|}
\hline Areas & Code & $f$ \\
\hline \multirow{6}{*}{ Listening } & The words are a little different & 1 \\
\hline & Listening is not utile & 2 \\
\hline & Listening is similar to speaking & 1 \\
\hline & Listening takes place spontaneously & 1 \\
\hline & Listening is continuously used in daily life & 1 \\
\hline & Listening education is not necessary & 1 \\
\hline \multirow{7}{*}{ Reading } & Finding reading easy & 1 \\
\hline & Learning more by reading & 1 \\
\hline & Finding reading useful & 1 \\
\hline & Learning the language rules by reading & 1 \\
\hline & Reading is useful for speech & 1 \\
\hline & Understanding every word he/she reads & 1 \\
\hline & Enjoying to read & 1 \\
\hline \multirow{8}{*}{ Speaking } & Finding reading useful & 8 \\
\hline & Learning how to communicate & 1 \\
\hline & The ability to use what he/she learns in daily life & 1 \\
\hline & Being the most useful skill in daily life & 2 \\
\hline & Not solving any problem without speaking & 1 \\
\hline & The necessity of speaking and communicating & 1 \\
\hline & The fact that a person who can speak can also write & 1 \\
\hline & Starting to enjoy speaking with time & 1 \\
\hline \multirow{11}{*}{ Writing } & Finding writing useful & 4 \\
\hline & Similarities in the alphabets & 1 \\
\hline & Not using writing often & 1 \\
\hline & Having difficulties in writing & 2 \\
\hline & Not to be able to write about a specific topic & 1 \\
\hline & Not using the daily conversations in writing & 2 \\
\hline & Using writing in studies & 1 \\
\hline & Paying attention to the grammar and letters & 1 \\
\hline & Learning grammar by writing & 1 \\
\hline & The importance of spelling rules & 1 \\
\hline & The importance of writing on stating one's opinion & 1 \\
\hline \multirow{7}{*}{ Grammar } & Finding grammar useful & 7 \\
\hline & Finding Turkish grammar easy & 1 \\
\hline & Finding grammar useful in terms of writing & 1 \\
\hline & Not being able to translate the sentences into Turkish that are thought in native language & 1 \\
\hline & Finding grammar difficult to learn & 2 \\
\hline & The necessity of learning grammar rules first & 4 \\
\hline & Grammar knowledge is being related to writing & 1 \\
\hline
\end{tabular}

The students pointed out about listening that, the words being little different, listening is not helpful, having similarities with writing, it occurs spontaneously, it is used often in daily life, and it is not necessary to have 
listening classes.

"It is not important for me to take the listening classes because we are listening to teachers and watching Turkish soap operas. Listening is already in life. There is no need to have a listening course." (5)

"Listening is hard for me. I am missing words when someone is speaking." (20)

The students expressed about reading that, they find it easy and useful, they learn more by reading, they learn grammar by reading, it is useful for speaking, they understand everything and like reading.

"Reading is easy to me. I learn more while reading." (16)

"I am learning how to set up a sentence while reading Turkish books, and where to place the subject. The more I read, the better I speak. So I find reading very useful." (20)

The students stated that they found speaking very helpful in new language learning. They learn how to communicate by speaking. They could use what they learn in class in their daily life. They find speaking as the most useful skill in life. They cannot handle anything without speaking. They feel the necessity of speaking and communicating. They also stated that a person who can speak is also able to write and with time they start to like speaking Turkish.

"It does not matter if you know writing and grammar, but if you do not talk, you do not live that language. Because the most common activity in life is speaking." (5)

"I did not like to talk when I first came to Turkey. I was hesitating cause I could not talk, but I love talking now." (16)

The students stated that they find writing very useful in terms of language learning. They find similarities between Turkish and their native language. They cannot write about a specific subject. They stated that in writing the daily conversation, style could not be used. They mostly used writing while studying. They also stated their necessity of paying attention to grammar knowledge and letters. They commented that the grammar is also learned while writing and emphasized the importance of spelling rules while expressing an opinion.

"I have difficulty in writing because the text should be correctly written. If I write it as it is spelled, then it becomes street language. Street and literary language are not the same. Some words are not used when writing. I also want to write about a topic, I know exactly what to write, but somehow I can not translate my thoughts into Turkish and write grammatically correct." (4)

"If you can write you can read as well. To study writing is necessary and a better way." (8)

"In writing it is necessary to pay attention to grammar and letters. We should not write as we spell, what you speak and write are different." (11)

"Knowing the spelling rules are important to me. I want to know how the spelling rules are in Turkish for example where to put dot and comma." (18)

The students stated that they find the grammar necessary and easy, useful for writing, some of them think in their native language and cannot translate into Turkish, it is hard to learn the grammar, firstly it is necessary to know the grammar, and there is a connection between writing and grammar.

"You always learn grammar as you write. After you learn grammar, you know Turkish better. So to learn Turkish better, you must learn grammar first." (15)

"Most useful course is the grammar lesson. The teacher explains the grammar rules. We know the other lessons. Not too hard for me." (18)

\section{Discussion and Conclusion}

Turkmen students generally criticized the education system in Turkmenistan negatively and stated that the system is based on materiality. On the other hand, Azerbaijani students expressed their satisfaction with the education system in their country. It was determined that the Azerbaijani and Turkmen students were all satisfied with the education system in Turkey and they enjoyed it.

International students who learned Turkish used positive expressions related to Turkish. They stated that they found Turkish close to their language, it was an easy language, it was easy to communicate, and it was a beautiful language. The students described Turkish as beautiful, polite, fun, like music, warm and easy. Especially Turkmen students find Turkish very polite when compared to their language. They expressed that during the day people give warm wishes while communicating with each other and said that they liked this situation very much.

The international students who are learning Turkish oriented for their subject for six months expressed that there 
was no need for listening classes. The students state that the listening process already occurs while they follow what their teachers speak. It is thought-provoking that students do not need an additional activity for listening. The students stated that they found it easy and useful to read, they learned more by reading, they learned the rules of language while reading and they liked reading texts.

The students stated that they found the speaking classes useful, they learned to communicate through conversation, and they could use what they learned in class in everyday life. They also stated that speaking is the most used skill in life, they cannot work without talking, they feel the need to talk and communicate.

The reason for why the students found speaking the most useful ability might be because they learn Turkish in Turkey. According to Acik, (2008), thirty-three percent of the participants stated that they had difficulty in speaking skills. Contrary to this study, in our study, it was seen that participants find the verbal ability the most popular and embraced skill. This may be since the participants in this study were Turkmen and Azerbaijani.

The students claimed that writing skills were necessary and essential, but they had difficulties in writing. Since the alphabets are similar, they do not have many challenges in terms of the alphabet. However, it was not possible for them to write an article about a subject due to the fact that they need to pay so much attention to the grammar and spelling rules. Acik (2008), Bagci and Basar (2013), Bicer, Coban, and Cakır (2014) also found out that international students who learn Turkish have difficulties in writing skills.

The students stated that grammar was useful in terms of writing and that it was necessary to know the grammar rules, but that the grammar was difficult to learn and that grammar was related to writing. Besides, they stated that writing and grammar were inseparable. For other language areas, such an interrelation is generally not expressed by the students. The Baskan (1975) states that the grammar of the mother tongue learning does not create any difficulties, and the reason for why learning the foreign language is more difficult is due to the differences in techniques of learning the language of the mother tongue and learning the foreign language.

In this study, it is seen that Turkmen students were not satisfied with the education system in their country while Azerbaijanis were satisfied and both groups liked the education system in Turkey. It is determined that the learners had positive and beautiful thoughts about Turkish. In terms of linguistic areas they did not find listening necessary, they did not mind much about reading, and on the contrary, they cared a lot about speaking, and they gave importance to writing and grammar, though they had difficulties in them.

\section{References}

Acik, F. (2008). Problems and proposed solutions to the Turkish foreign incongruously in Turkey. Eastern Mediterranean University Faculty of Education Department of Turkish Education International Turkish Education and Training Symposium. Retrieved from http://turkoloji.cu.edu.tr/YENI\%20TURK\%20DILI/ fatma_acik_yabancilara_turkce_ogretimi.pdf

Bagci, H., \& Basar, U. (2013). Writing education. In M. Durmus, \& O. Saricoban (Eds.), Handbook on teaching Turkish to foreigners (pp. 309-331). Ankara: Grafiker.

Barnett, M. A. (1988). Reading through context: How real and perceived strategy use affects L2 comprehension. The Modern Language Journal, 72(2), 150-162. https://doi.org/10.1111/j.1540-4781.1988.tb04177.x

Baskan, O. (1975). The place of grammar in foreign language teaching. Journal of Turkish Language and Literature, 31(85), 435-438. Retrieved from http://www.tdk.gov.tr/images/css/TDD/1975s285/1975s285 04_yabanci.pdf

Bicer, N., Coban, İ., \& Bakir, S. (2014). The problems faced by the foreign students learning Turkish: Ataturk University case. The Journal of International Social Research, 7(29), 125-135. Retrieved from http://www.sosyalarastirmalar.com/cilt7/sayi29pdf/bicer_nursat_vdx.pdf

Bygate, M. (2001). Speaking. In. R. Carter, \& D. Nunan (Eds.), The Cambridge guide to teaching English to speakers of other languages (pp. 14-20). Cambridge: Cambridge University Press. https://doi.org/10.1017/cbo9780511667206.003

Candas-Karababa, Z. C. (2009). Teaching Turkish as a foreign language and problems encountered. Ankara University Journal of Faculty of Educational Science, 42(2), 265-277. https://doi.org/10.1501/egifak_0000001185

Demir, S., \& Erdogan, A. (2017). The role of teaching grammar in first language education. European Journal of Educational Research, 7(14), 87-101. https://doi.org/10.12973/eu-jer.7.1.87

Keskin, F., \& Okur, A. (2013). Reading education. In. M. Durmus \& O. Saricoban (Eds.), Handbook on teaching 
Turkish to foreigners (pp. 293-308). Ankara: Grafiker.

Mete, F. (2015). Language and foreign/second language education concepts. In. A. Saricoban (Ed.), Methodology of teaching Turkish as a foreign language (pp. 11-68). Ankara: Ani.

Miles, M. B. \& Huberman, A. M. (1994). Qualitative data analysis: An expanded sourcebook. London: Sage.

Punch, K. F. (2005). Introduction to social research: Quantitative and qualitative approaches. London: Sage.

Rost, M. (2001). Listening. In. R. Carter, \& D. Nunan (Eds.), The Cambridge guide to teaching English to speakers of other languages (pp. 7-13). Cambridge: Cambridge University Press. https://doi.org/10.1017/cbo9780511667206.002

Ucgun, D. (2007). The factors affecting the speaking education. Erciyes University Journal of the Institute of Social Sciences, 22(1), 59-67. Retrieved from http://dergipark.gov.tr/download/article-file/219390

Ungan, S. (2013). Language and world languages. In. M. Durmus, \& O. Saricoban (Eds.), Handbook on teaching Turkish to foreigners (pp. 15-22). Ankara: Grafiker.

Williams, R. (1986). Top ten principles for teaching reading. ELT Journal, 40(1), 42-45. https://doi.org/10.1093/elt/40.1.42

\section{Copyrights}

Copyright for this article is retained by the author(s), with first publication rights granted to the journal.

This is an open-access article distributed under the terms and conditions of the Creative Commons Attribution license (http://creativecommons.org/licenses/by/4.0/). 